\title{
Sistem Pendukung Keputusan Pemilihan Jurusan Kuliah Dengan Metode Analytical Hierarchy Process (AHP) Berbasis Web Pada SMAN 1 Kramatwatu
}

\author{
Rizki Fatullah ${ }^{1}$, Huswatun Hasanah ${ }^{2}$, Dwi Rizky ${ }^{3}$ \\ email: rizkifath@unbaja.ac.id ${ }^{1}$, huswatunhasanah@unbaja.ac.id², dwirizkysitinjak@gmail.com³ \\ Universitas Banten Jaya ${ }^{1,2,3}$
}

\begin{abstract}
Abstrak
Sistem pendukung keputusan (SPK) merupakan suatu sistem pemilihan yang biasa dipakai untuk menentukan pilihan sesuai dengan kriteria dan alternatif yang sudah ditentukan sebelumnya. Berdasarkan proses wawancara yang dilakukan kepada siswa kelas XII IPA Sekolah Menengah Atas, banyak siswa yang memiliki keraguan dalam menentukan jurusan saat melanjutkan pendidikan ke tingkat perguruan tinggi. Sebagian besar dari mereka masih ragu apakah keinginan untuk dapat berkuliah pada salah satu jurusan dapat dijalani dengan lancar berdasarkan pencapaian hasil proses belajar yang diikuti di Sekolah Menengah Atas. Tujuan penelitian ini adalah membangun sebuah Sistem Pendukung Keputusan (SPK) yang dapat memberikan referensi maupun rekomendasi kepada siswa mengenai jurusan yang sesuai dengan nilai sekolah siswa. Penelitian dilakukan di SMAN 1 Kramatwatu. SPK yang dikembangkan menggunakan metode Analytical Hierarchy Process (AHP). Hasil uji coba yang dilakukan adalah dengan menggunakan SPK ini, telah didapat referensi pemilihan jurusan yang dapat direkomendasikan kepada siswa yang menjadi contoh uji.
\end{abstract}

Kata kunci: $A H P$, Jurusan, $S P K$

\section{Pendahuluan}

Abad pengetahuan atau yang lebih dikenal dengan sebutan era globalisasi merupakan wujud dari suatu era yang menuntut kemampuan melakukan kompilasi dan sintesis berbagai informasi menjadi suatu proposisi pengetahuan dan teknologi. Salah satu bentuk teknologi yaitu merupakan sistem pendukung keputusan. Sistem pendukung keputusan (SPK) pertama kali diungkapkan pada awal tahun 1970-an oleh Michael S. Scott Morton dengan istilah Management Decision System. Sistem tersebut merupakan suatu sistem berbasis komputer yang ditujukan untuk membantu pengambil keputusan dengan memanfaatkan data serta model tertentu untuk memecahkan berbagai persoalan yang bersifat semi terstruktur. SPK tidak dimaksudkan untuk mengotomatisasi pengambilan keputusan, tetapi memberikan perangkat interaktif yang memungkinkan pengambilan keputusan untuk melakukan berbagai analisis menggunakan model model yang tersedia[1].

Salah satu metode yang terdapat dalam sistem pendukung keputusan yaitu Analytical Hierarchy Process (AHP). Metode AHP merupakan salah satu model untuk pengambilan keputusan yang dapat membantu kerangka berpikir manusia. Analytic Hierarchy Process (AHP) dapat menyelesaikan masalah multi kriteria yang kompleks menjadi suatu hirarki. Masalah yang kompleks dapat diartikan bahwa kriteria dari suatu masalah yang begitu banyak (multikriteria), struktur masalah yang belum jelas, ketidakpastian pendapat dari pengambil keputusan, pengambil keputusan lebih dari satu orang, serta ketidakakuratan data yang tersedia[2].

Penelitian ini diawali dengan wawancara kepada guru Bimbingan dan Konseling (BK) SMAN 1 Kramatwatu tentang siswa yang berkonsultasi mengenai masalah yang sedang dihadapi, baik masalah dalam proses pembelajaran maupun masalah yang dihadapi sehari-hari. Selain itu, ditelusuri juga bagaimana siswa berkonsultasi tentang jurusan kuliah yang ingin diambil dan Universitas mana yang akan dituju ketika melanjutkan pendidikan ke perguruan tinggi. Dengan demikian, guru Bimbingan dan Konseling akan membimbing siswa dalam memilih dan membuat keputusan mengenai jurusan yang akan dipilih, merencanakan studi lanjut jurusan, dan bagaimana menilai kemampuan secara akademik.

Pada bulan Juli 2021 sudah mulai diadakan pembukaan pendaftaran untuk mahasiswa baru di setiap Universitas negeri maupun swasta. Sedangkan, masih banyak siswa SMAN 1 Kramatwatu yang belum 
mengetahui jurusan mana yang akan dipilih ketika ingin melanjutkan pendidikan ke perguruan tinggi. Siswa yang ada di SMAN 1 Kramatwatu tidak memiliki wawasan yang cukup untuk menentukan jurusan kuliah. Hal ini dapat dibuktikan dengan banyaknya siswa yang datang ke guru Bimbingan dan Konseling untuk mendapatkan saran mengenai jurusan yang sesuai dengan siswa tersebut.

Pengambilan keputusan menentukan jurusan kuliah juga merupakan salah satu bagian dari penentuan karir di masa depan. Pengambilan keputusan dalam menentukan karir merupakan salah satu tugas perkembangan yang harus dipenuhi oleh remaja. Remaja mengalami kebingungan dalam menentukan pilihan dari berbagai macam jurusan di perguruan tinggi yang menawarkan keahlian tertentu pada tiap-tiap jurusan. Hal ini mengakibatkan beberapa individu memilih jurusan yang tidak sesuai dengan dirinya[3].

Faktor lain yang membuat siswa SMAN 1 Kramatwatu ragu dalam menentukan jurusan yang sesuai adalah belum mengetahui apakah pencapaian hasil proses belajar yang saat ini diikuti di sekolah sesuai dengan jurusan yang mereka inginkan. Melalui tes nilai sekolah, siswa dapat lebih mengetahui potensi dirinya termasuk kelebihan dan kekurangannya sehingga dapat membantu untuk membuat keputusan dalam menentukan karir atau jurusan yang sesuai.

Beberapa penelitian terdahulu yang sejenis telah dilakukan, di antaranya penelitian tentang SPK untuk membantu siswa SMA Negeri di Kota Pasuruan menggunakan Metode AHP[4]. Hal yang jadi pertimbangan adalah nilai Ujian Akhir Nasional, sistem zonasi, biaya, serta jurusan di sekolah tujuan. Penelitian ini dapat membantu calon siswa dalam memilih SMA Negeri di Kota Pasuruan sehingga siswa dapat memilih mana sekolah yang tepat untuknya.

Penelitian lain dilakukan yaitu Sistem Pendukung Keputusan dalam memilih Sekolah Dasar (SD) dengan Metode AHP di Gugus Sungai Jingah Kecamatan Banjarmasin Utara[5]. Pemilihan ini memiliki beberapa faktor kriteria seperti Pendidikan, Fasilitas, Lokasi, Ekstrakurikuler dan Spiritual. Dari faktor tersebut, orang tua murid calon siswa SD memilih kriteria menurut persepsi masing- masing untuk menentukan Sekolah Dasar bagi putra dan putrinya.

Peneliti lainnya yaitu Sistem Penunjang Keputusan Untuk Membantu Calon SiswaSiswi Memilih SMK Di Malang [6]. Metode yang digunakan adalah AHP. Kriteria-kriteria yang dibutuhkan yaitu biaya SPP, total biaya administrasi, fasilitas, jurusan, akreditasi, dan ekstrakurikuler.

Berdasarkan permasalahan yang telah diuraikan sebelumnya dan menganalisis beberapa penelitian terdahulu, perlu dibuat suatu aplikasi pemilihan jurusan kuliah berbasi web yang dapat menjadi rekomendasi siswa dalam memilih jurusan kuliah ketika ingin melanjutkan pendidikan ke perguruan tinggi. Oleh karena itu, penulis bermaksud mengambil topik penelitian ini dengan judul "Sistem Pendukung Keputusan Pemilihan Jurusan Kuliah Dengan Metode Ahp (Analytical Hierarchy Process) Berbasis Website Pada Sma Negeri 1 Kramatwatu".

\section{Metode Penelitian}

\section{A. Metodologi Penelitian}

Metodologi penelitian adalah ilmu yang digunakan untuk memperoleh perencanaan dengan tata cara tertentu. Pada penelitian kali ini, dibangun dengan menggunakan desain perencanaan sehingga dapat mudah dilakukan. Ilustrasi metodologi penelitian dapat dilihat pada Gambar 1 .

\section{B. Data Penelitian}

Data yang dikumpulkan untuk menunjang penelitian ini diperoleh dari guru BK dan siswa dari SMA Negeri 1

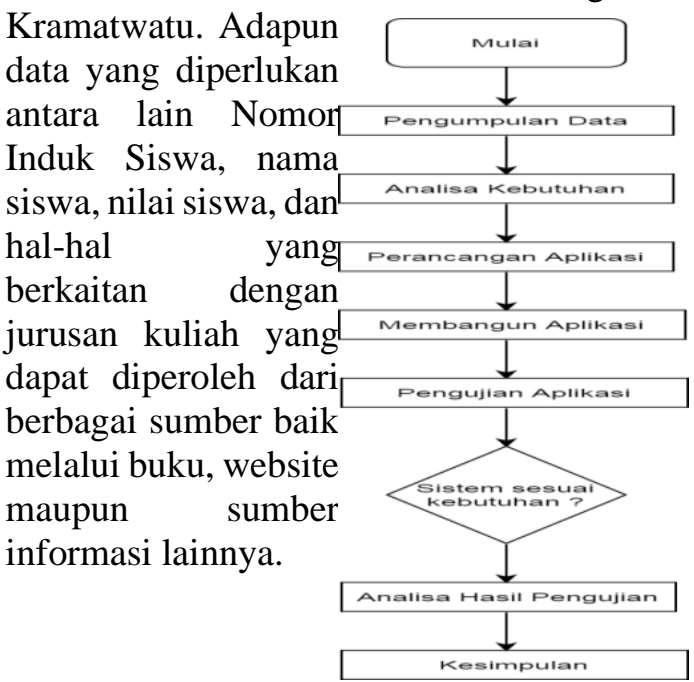

Gambar 1. Diagram Alir Metodologi Penelitian 


\section{Use Case Diagram}

Use Case Diagram merupakan gambaran atau representasi dari interaksi yang terjadi antara sistem dengan aktor pada aplikasi yang sedang berjalan dapat dilihat pada gambar 2 .

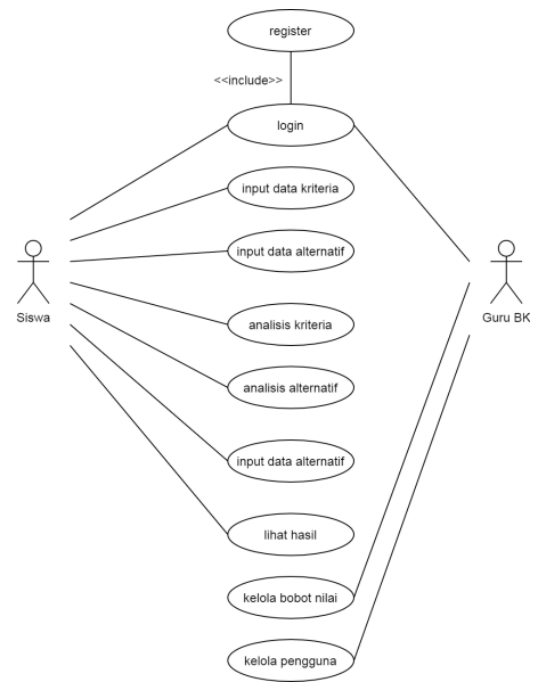

Gambar 2. Use Case Diagram

\section{Perancangan Antarmuka Aplikasi}

Perancangan antarmuka dirancang sebagai gambaran awal aplikasi yang akan dibangun. Perancangan antarmuka aplikasi meliputi beberapa pengguna diantaranya siswa dan guru bk (admin). Struktur antarmuka aplikasi dapat dilihat pada gambar 3 dan struktur antarmuka siswa pada gambar 4.

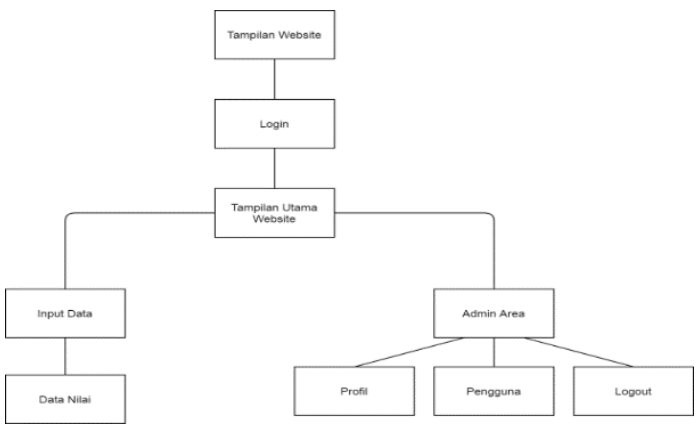

Gambar 4. Struktur Antarmuka Aplikasi

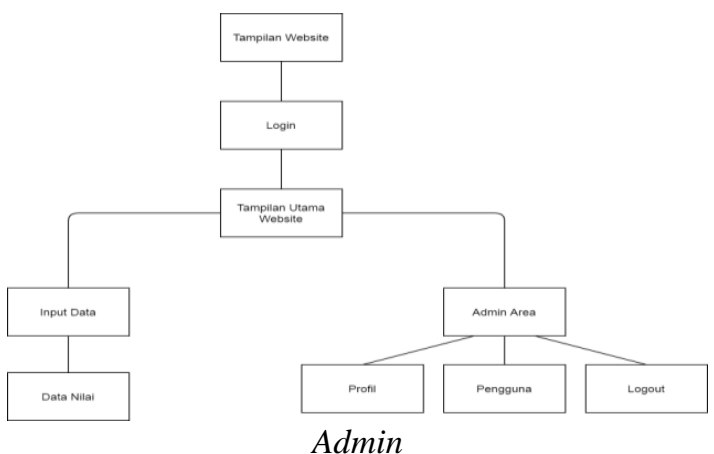

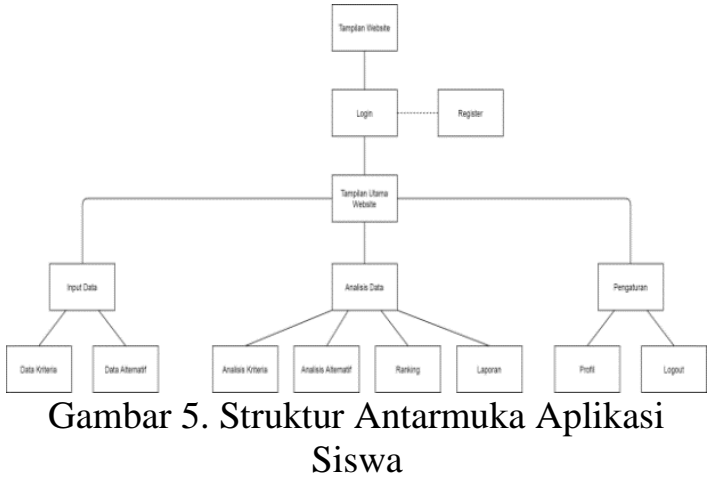

3. Hasil dan Pembahasan

Pada bagian ini dibahas mengenai perhitungan dan pengujian dari sistem pendukung keputusan dengan metode Analytical Hierarchy Process (AHP). Langkah pertama dalam menentukan prioritas elemen dengan membuat perbandingan berpasangan. Data didapat dari observasi, literatur maupun wawancara yang langsung membandingkan kriteria dan alternatif sesuai dengan tabel kepentingan.

Tabel 1. Perbandingan Berpasangan

\begin{tabular}{|c|c|c|c|c|c|}
\hline Kriteria & Matematika & Fisika & Biologi & Kimia & B.Inggris \\
\hline Matematika & 1 & 3 & 3 & 7 & 0.200 \\
\hline \begin{tabular}{|l|} 
Fisika \\
\end{tabular} & 0.333 & 1 & 3 & 5 & 0.200 \\
\hline Biologi & 0.333 & 0.333 & 1 & 6 & 3 \\
\hline Kimia & 0.143 & 0.200 & 0.167 & 1 & 0.333 \\
\hline B.Inggris & 5 & 5 & 0.333 & 3 & 1 \\
\hline Jumlah & 6.80952381 & 9.533333333 & $\begin{array}{l}7.5 \\
\end{array}$ & 22 & 4.73333333 \\
\hline
\end{tabular}

Perbandingan kriteria dilakukan dengan mengisi nilai bobotnya berdasarkan tingkat kepentingan dari kriteria tersebut. Nilai diatas sudah ditentukan dari survey/keinginan/ hasil pertanyaan.

Tabel 2. Nilai Eigen

\begin{tabular}{|l|c|c|c|c|c|r|r|}
\hline \multicolumn{1}{|c|}{ Kriteria } & Matematika & Fisika & Biologi & Kimia & B.Inggris & Jumlah & Rata rata \\
\hline Matematika & 0.147 & 0.315 & 0.400 & 0.318 & 0.042 & 1.222 & 0.244395 \\
\hline Fisika & 0.0490 & 0.1049 & 0.4000 & 0.2273 & 0.0423 & 0.823 & 0.164674 \\
\hline Biologi & 0.0490 & 0.0350 & 0.1333 & 0.2727 & 0.6338 & 1.124 & 0.224756 \\
\hline Kimia & 0.0210 & 0.0210 & 0.0222 & 0.0455 & 0.0704 & 0.180 & 0.036011 \\
\hline B.Inggris & 0.7343 & 0.5245 & 0.0444 & 0.1364 & 0.2113 & 1.651 & 0.330163 \\
\hline
\end{tabular}

Selanjutnya menentukan nilai CR (Consistency Ratio) sebagaimana perhitungan dibawah ini :

$$
\begin{aligned}
& \mathrm{CR}=\mathrm{CI} / \mathrm{IR} \\
& \mathrm{CI}=(\lambda \max -\mathrm{n}) /(\mathrm{n}-1) \\
& \lambda \max =7.274803604 \\
& \mathrm{CI}=0.568700901 \\
& \mathrm{CR}=0.507768662
\end{aligned}
$$

Tabel 3. Matrix Perbandingan Alternatif Pada Kriteria Matematika

\begin{tabular}{|l|c|c|c|c|c|}
\hline Matematika & Teknik Informatika & Teknik Industri & Teknik Lingkungan & Teknik Sipil & Teknik Mesin \\
\hline Teknik Informatika & 1 & 0.143 & 0.333 & 0.200 & 5 \\
\hline Teknik Industri & 7 & 1 & 0.333 & 0.143 & 7 \\
\hline Teknik Lingkungan & 3 & 3 & 1 & 0.333 & 5 \\
\hline Teknik Sipil & 5 & 7 & 3 & 1 & 7 \\
\hline Teknik Mesin & 0.200 & 0.143 & 0.200 & 0.143 & 1 \\
\hline Jumlah & 16.2 & 11.28571429 & 4.866666667 & 1.819047619 & 25 \\
\hline
\end{tabular}

Pada tahap ini menghitung perbandingan alternatif pada kriteria Matematika. 
Tabel 4. Nilai Eigen Kriteria Matematika

\begin{tabular}{|l|c|c|c|c|c|r|r|r|}
\hline Matematika & Teknik Informatik & Teknik Industri & Teknik Lingkunga & Teknik Sipil & Teknik Mesin & Jumlah & Rata rata \\
\hline Teknik Intormatil & 0.062 & 0.013 & 0.068 & 0.110 & 0.200 & 0.453 & 0.091 \\
\hline Teknik Industri & 0.432 & 0.089 & 0.068 & 0.079 & 0.280 & 0.948 & 0.190 \\
\hline Teknnk Lingkunga & 0.185 & 0.266 & 0.205 & 0.183 & 0.200 & 1.040 & 0.208 \\
\hline Teknik Sipil & 0.309 & 0.620 & 0.616 & 0.550 & 0.280 & 2.375 & 0.475 \\
\hline Teknik Mesin & 0.012 & 0.013 & 0.041 & 0.079 & 0.040 & 0.185 & 0.037 \\
\hline
\end{tabular}

Selanjutnya menentukan nilai CR (Consistency Ratio) sebagaimana perhitungan dibawah ini :

$\mathrm{CR}=\mathrm{CI} / \mathrm{IR}$

$\mathrm{CI}=(\lambda \max -\mathrm{n}) /(\mathrm{n}-1)$

$\lambda \max =6.405580951$

$\mathrm{CI}=0.351395238$

$\mathrm{CR}=0.313745748$

Tabel 5. Matrix Perbandingan Alternatif Pada Kriteria Fisika

\begin{tabular}{|l|c|c|c|c|c|}
\hline \multicolumn{1}{|c|}{ Fisika } & Teknik Informatika & Teknik Industri & Teknik Lingkungan & Teknik Sipil & Teknik Mesin \\
\hline Teknik Informatika & 1 & 0.200 & 0.143 & 0.333 & 0.333 \\
\hline Teknik Industri & 5 & 1 & 5 & 4 & 5 \\
\hline Teknik Lingkungan & 7 & 0.200 & 1 & 6 & 3 \\
\hline Teknik Sipil & 3 & 0.250 & 0.167 & 1 & 5 \\
\hline Teknik Mesin & 3 & 0.200 & 0.333 & 0.200 & 1 \\
\hline Jumlah & \multicolumn{2}{c}{19.85} & 6.642857143 & 11.53333333 & 14.33333333 \\
\hline
\end{tabular}

Pada tahap kedua ini dilakukan perhitungan perbandingan alternatif pada kriteria Fisika, kemudian dilakukan kembali perhitungan untuk menentukan nilai eigen kriteria Fisika.

Tabel 6. Nilai Eigen

\begin{tabular}{|l|c|c|c|c|c|r|r|r|}
\hline \multicolumn{1}{|c|}{ Fisika } & Teknik Informatik & Teknik Industri| & Teknik Lingkunga & Teknik Sipil & Teknik Mesin & Jumlah & Rata rata \\
\hline Teknik Informatili & 0.053 & 0.108 & 0.022 & 0.029 & 0.023 & 0.234 & 0.047 \\
\hline Teknik Industri & 0.263 & 0.541 & 0.753 & 0.347 & 0.349 & 2.252 & 0.450 \\
\hline Teknik Lingkunga & 0.368 & 0.108 & 0.151 & 0.520 & 0.209 & 1.357 & 0.271 \\
\hline Teknik Sipil & 0.158 & 0.135 & 0.025 & 0.087 & 0.349 & 0.754 & 0.151 \\
\hline Teknik Mesin & 0.158 & 0.108 & 0.050 & 0.017 & 0.070 & 0.403 & 0.081 \\
\hline
\end{tabular}

Menghitung nilai Consistency Ratio :

$\mathrm{CR}=\mathrm{CI} / \mathrm{IR}$

$\mathrm{CI}=(\lambda \max -\mathrm{n}) /(\mathrm{n}-1)$

$\lambda \max =6.420873182$

$\mathrm{CI}=0.355218296$

$\mathrm{CR}=0.317159192$

Tabel 7. Matrix Perbandingan Alternatif Pada Kriteria Biologi

\begin{tabular}{|l|c|c|c|c|c|}
\hline \multicolumn{1}{|c|}{ Biologi } & Teknik Informatika & Teknik Industri & Teknik Lingkungan & Teknik Sipil & Teknik Mesin \\
\hline Teknik Informatika & 1 & 0.200 & 0.333 & 0.500 & 2 \\
\hline Teknik Industri & 5 & 1 & 5 & 3 & 3 \\
\hline Teknik Lingkungan & 3 & 0.200 & 1 & 5 & 5 \\
\hline Teknik Sipil & 2 & 0.333 & 0.200 & 1 & 2 \\
\hline Teknik Mesin & 0.500 & 0.333 & 0.200 & 0.500 & 1 \\
\hline Jumlah & 11.5 & 2.066666667 & 6.733333333 & \multicolumn{2}{c|}{10} \\
\hline
\end{tabular}

Pada tahap ketiga ini dilakukan perhitungan perbandingan alternatif pada kriteria Biologi, kemudian dilakukan kembali perhitungan untuk menentukan nilai eigen kriteria Biologi.

Tabel 8. Nilai Eigen

\begin{tabular}{|l|l|l|l|l|l|l|r|r|}
\hline \multicolumn{2}{|c|}{ Biologi } & Teknnik Iformatike & Teknik Industri & Teknik Lingknnga & Teknik Sipil & Teknik Mesin & Jumlah & Rata rata \\
\hline Teknik Informatin & 0.087 & 0.097 & 0.050 & 0.050 & 0.154 & 0.437 & 0.087 \\
\hline Teknik Industri & 0.435 & 0.484 & 0.743 & 0.300 & 0.231 & 2.192 & 0.438 \\
\hline Teknnik Lingkunga & 0.261 & 0.097 & 0.149 & 0.500 & 0.385 & 1.391 & 0.278 \\
\hline Teknik Sipil & 0.174 & 0.161 & 0.030 & 0.100 & 0.154 & 0.619 & 0.124 \\
\hline Teknik Mesin & 0.043 & 0.161 & 0.030 & 0.050 & 0.077 & 0.361 & 0.072 \\
\hline
\end{tabular}

Menghitung nilai Consistency Ratio :

$\mathrm{CR}=\mathrm{CI} / \mathrm{IR}$

$\mathrm{CI}=(\lambda \max -\mathrm{n}) /(\mathrm{n}-1)$

$\lambda \max =5.961353638$
$\mathrm{CI}=0.24033841$

$\mathrm{CR}=0.214587866$

Tabel 9. Matrix Perbandingan Alternatif Pada Kriteria Kimia

\begin{tabular}{|l|c|c|c|c|c|}
\hline \multicolumn{1}{|c|}{ Kimia } & Teknik Informatika & Teknik Industri & Teknik Lingkungan & Teknik Sipil & Teknik Mesin \\
\hline Teknik Informatika & 1 & 0.200 & 0.333 & 0.333 & 0.500 \\
\hline Teknik Industri & 5 & 1 & 5 & 3 & 5 \\
\hline Teknik Lingkungan & 3 & 0.200 & 1 & 5 & 3 \\
\hline Teknik Sipil & 3 & 0.333 & 0.200 & 1 & 3 \\
\hline Teknik Mesin & 2.000 & 0.200 & 0.333 & 0.333 & 1 \\
\hline Jumlah & 14 & 1.933333333 & 6.866666667 & 9.6666666667 & 12.5 \\
\hline
\end{tabular}

Pada tahap keempat ini dilakukan perhitungan perbandingan alternatif pada kriteria Kimia, kemudian dilakukan kembali perhitungan untuk menentukan nilai eigen kriteria Kimia. Tabel 10. Nilai Eigen

\begin{tabular}{|l|l|l|l|l|l|r|r|}
\hline \multicolumn{1}{|c|}{ Kimia } & Teknik Informatikik & Teknik Industri & Teknik Lingkunga & Teknik Sipil & Teknik Mesin & Jumlah & Rata rata \\
\hline Teknik Informatil & 0.071 & 0.103 & 0.049 & 0.034 & 0.040 & 0.298 & 0.060 \\
\hline Teknik Industri & 0.357 & 0.517 & 0.728 & 0.310 & 0.400 & 2.313 & 0.463 \\
\hline Teknik Lingknga & 0.214 & 0.103 & 0.146 & 0.517 & 0.240 & 1.221 & 0.244 \\
\hline Teknik Sipil & 0.214 & 0.172 & 0.029 & 0.103 & 0.240 & 0.759 & 0.152 \\
\hline Teknik Mesin & 0.143 & 0.103 & 0.049 & 0.034 & 0.080 & 0.409 & 0.082 \\
\hline
\end{tabular}

Menghitung nilai Consistency Ratio :

$\mathrm{CR}=\mathrm{CI} / \mathrm{IR}$

$\mathrm{CI}=(\lambda \max -\mathrm{n}) /(\mathrm{n}-1)$

$\lambda \max =5.896003431$

$\mathrm{CI}=0.224000858$

$\mathrm{CR}=0.200000766$

Tabel 11. Matrix Perbandingan Alternatif Pada Kriteria Bahasa Inggris

\begin{tabular}{|l|c|c|c|c|c|}
\hline \multicolumn{1}{|c|}{ B.Inggris } & Teknik Informatika & Teknik Industri & Teknik Lingkungan & Teknik Sipil & Teknik Mesin \\
\hline Teknik Informatika & 1 & 3 & 3 & 7 & 3 \\
\hline Teknik Industri & 0.333 & 1 & 5 & 3 & 5 \\
\hline Teknik Lingkungan & 0.333 & 0.200 & 1 & 0.333 & 5 \\
\hline Teknik Sipil & 0.143 & 0.333 & 3 & 1 & 3 \\
\hline Teknik Mesin & 0.333 & 0.200 & 0.200 & 0.333 & 1 \\
\hline Jumlah & 2.142857143 & 4.733333333 & $12.2 \quad 11.66666667$ & 17 \\
\hline
\end{tabular}

Pada tahap kelima ini dilakukan perhitungan perbandingan alternatif pada kriteria Bahasa Inggris, kemudian dilakukan kembali perhitungan untuk menentukan nilai eigen kriteria Bahasa Inggris.

Tabel 12. Nilai Eigen

\begin{tabular}{|c|c|c|c|c|c|c|c|}
\hline B.Inggris & Teknik Informatike & Teknik Industri & Teknik Lingkunge & Teknik Sipil & Teknik Mesin & Jumlah & Rata rata \\
\hline Teknik Informati & 0.467 & 0.634 & 0.246 & 0.600 & 0.176 & 2.123 & 0.42 \\
\hline Teknik Industri & 0.156 & 0.211 & 0.410 & 0.257 & 0.294 & 1.328 & 0.26 \\
\hline Teknik Lingkunge; & 0.156 & 0.042 & 0.082 & 0.029 & 0.294 & 0.602 & 0.12 \\
\hline Teknik Sipil & 0.067 & 0.070 & 0.246 & 0.086 & 0.176 & 0.645 & 0.12 \\
\hline Teknik Mesin & 0.156 & 0.042 & 0.016 & 0.029 & 0.059 & 0.302 & 0.06 \\
\hline
\end{tabular}

Menghitung nilai Consistency Ratio :

$\mathrm{CR}=\mathrm{CI} / \mathrm{IR}$

$\mathrm{CI}=(\lambda \max -\mathrm{n}) /(\mathrm{n}-1)$

$\lambda \max =6.167743567$

$\mathrm{CI}=0.291935892$

$\mathrm{CR}=0.260657046$

Tabel 13. Hasil Perangkingan

\begin{tabular}{|l|r|r|r|}
\hline \multicolumn{1}{|c|}{ JURUSAN } & Bobot Nilai & Persentase & Rank \\
\hline TEKNIK INFORMATIKA & 0.192 & $19 \%$ & 4 \\
\hline TEKNIK INDUSTRI & 0.323 & $32 \%$ & 1 \\
\hline TEKNIK LINGKUNGAN & 0.207 & $21 \%$ & 3 \\
\hline TEKNIK SIPIL & 0.217 & $22 \%$ & 2 \\
\hline TEKNIK MESIN & 0.061 & $6 \%$ & 5 \\
\hline \multicolumn{1}{|c|}{ Jumlah Nilai } & 1.000 & $100 \%$ & \\
\hline
\end{tabular}

Dari hasil perhitungan diatas didapatkan hasil persentase dan diperoleh ranking dari 
penetapan jurusan studi lanjut fakultas teknik, sebagai berikut:

a) Peringkat $1=$ Teknik Industri dengan persentase $32 \%$

b) Peringkat $2=$ Teknik Sipil dengan persentase $22 \%$

c) Peringkat $3=$ Teknik Lingkungan dengan presentase $21 \%$

d) Peringkat $4=$ Teknik Informatika dengan persentase $19 \%$

e) Peringkat $5=$ Teknik Mesin dengan presentase $6 \%$

\section{A. Hasil Penelitian}

Perancangan yang telah dilakukan terdiri dari perancangan prototype aplikasi, diagram alir aplikasi dan basis data. Perancangan menghasilkan sebuah aplikasi rekomendasi jurusan kuliah. Tampilan sistem diantaranya adalah siswa dan guru bk (admin).

\section{B. Tampilan Halaman}

Pada tampilan awal halaman ini terdapat form login yang dapat digunakan oleh siswa dan guru bk (admin). Tampilan halaman login dapat dilihat pada Gambar 6.

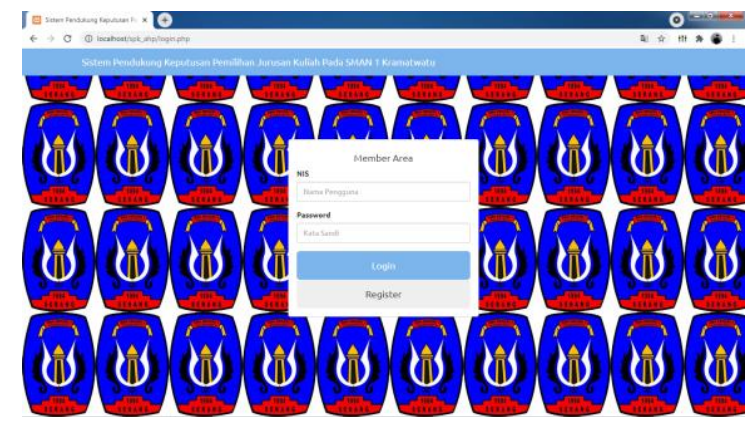

\section{Form Registrasi}

Form registrasi adalah halaman pembuka ketika Siswa ingin melakukan login kedalam sistem yang berfungsi sebagai identitas. Untuk dapat melewati form registrasi, Siswa dapat memasukan NIS, nama lengkap, password dan ulangi password lalu klik tombol registrasi. Tampilan registrasi dapat dilihat pada gambar 7 .

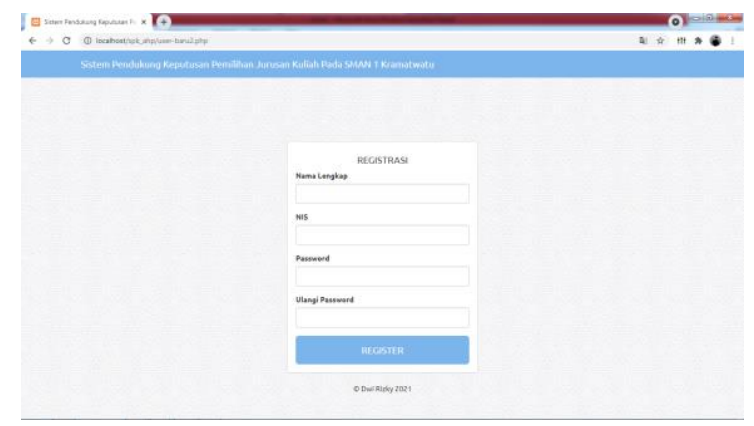

Gambar 7. Tampilan Registrasi

\section{Tampilan Halaman Admin}

Tampilan halaman admin terdiri dari beberapa menu yaitu data nilai, profil, pengguna, dan logout. Tampilan halaman dashboard admin dapat dilihat pada Gambar 8.

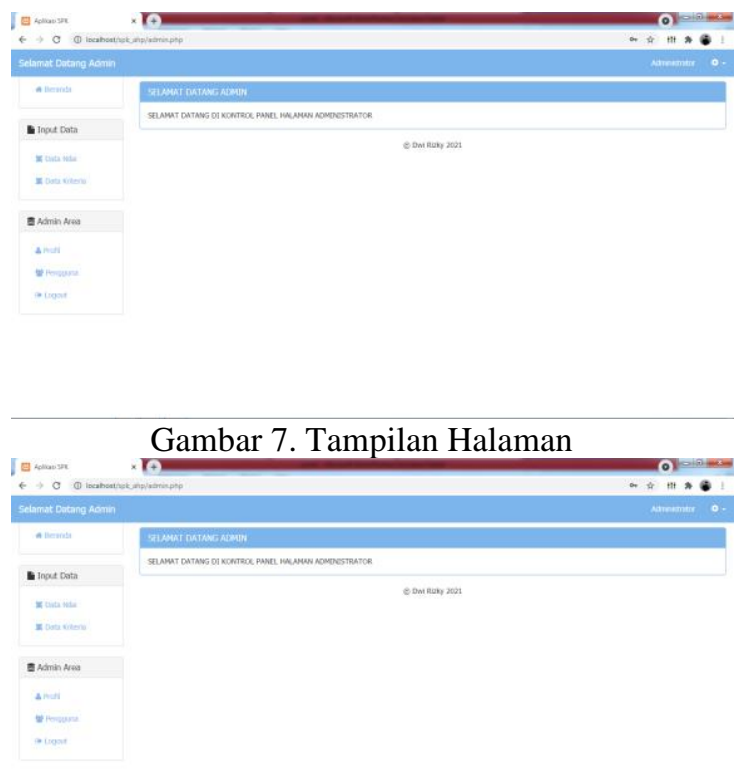

\section{Admin}

\section{E. Tampilan Halaman Siswa}

Halaman ini adalah menu utama Siswa. Terdapat beberapa menu di antaranya : menu input data yang berisikan data kriteria dan data alternatif, analisis data yang berisikan analisis kriteria, analisis alternatif, perangkingan dan laporan. Tampilan halaman siswa dapat dilihat pada gambar 9 .

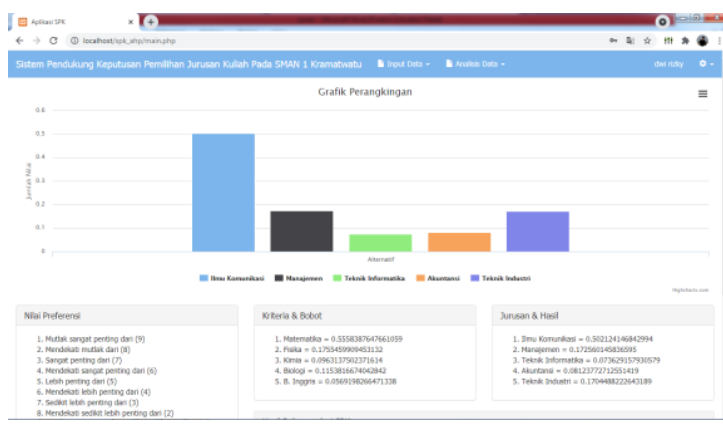

Gambar 9. Tampilan Halaman Siswa

\section{F. Menu Data Kriteria Siswa}

Halaman ini adalah menu data kriteria Siswa. Pada menu ini, Siswa dapat menambah data kriteria, mengedit data kriteria dan menghapus data kriteria. Tampilan menu data kriteria siswa dapat dilihat pada Gambar 10. 


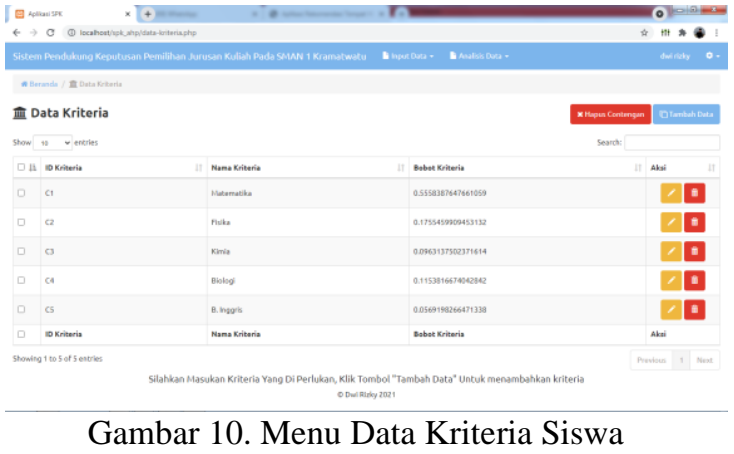

\section{G. Menu Data Alternatif Siswa}

Halaman ini adalah menu data alternatif Siswa. Pada menu ini, Siswa dapat menambah data alternatif, mengedit data alternatif dan menghapus data alternatif. Tampilan menu data alternatif siswa dapat dilihat pada Gambar 11.

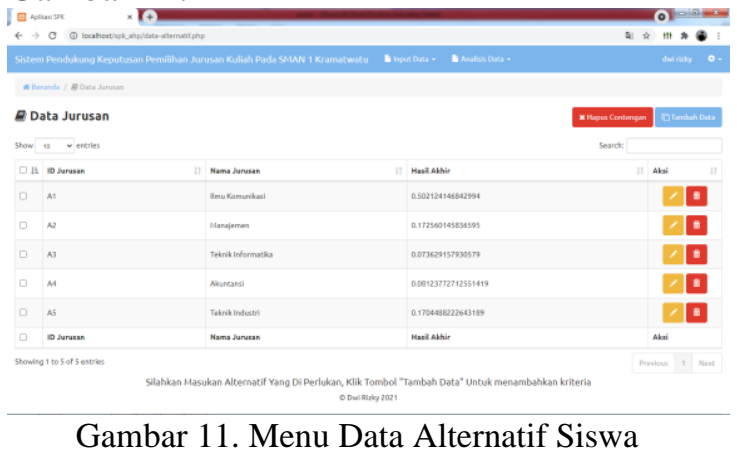

\section{H. Menu Analisis Kriteria Siswa}

Halaman ini adalah menu analisis kriteria Siswa. Pada menu ini, Siswa dapat menambah bobot nilai pembanding antara kriteria pertama yang ada di sebelah kiri dengan kriteria kedua yang ada di sebelah kanan, kemudian klik tombol proses. Tampilan menu analisis kriteria siswa dapat dilihat pada Gambar 12.

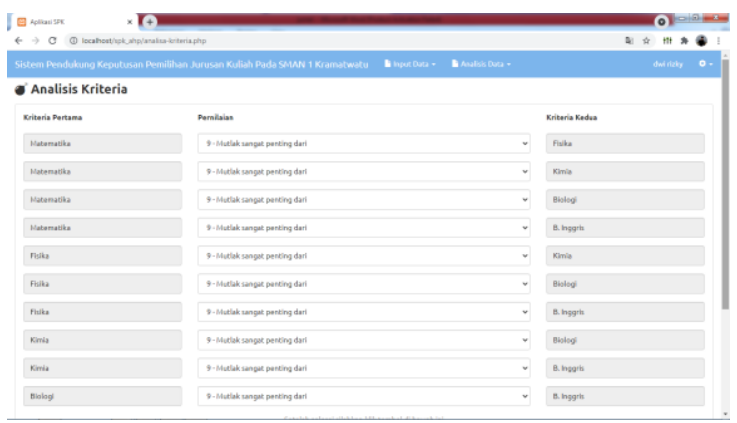

Gambar 12. Menu Analisis Kriteria Siswa

\section{Menu Analisis Alternatif Siswa}

Halaman ini adalah menu analisis alternatif Siswa. Pada menu ini, Siswa dapat menambah bobot nilai pembanding antara alternatif pertama yang ada di sebelah kiri dengan alternatif kedua yang ada di sebelah kanan, kemudian klik tombol proses.
Tampilan menu analisis alternatif siswa dapat dilihat pada Gambar 13.

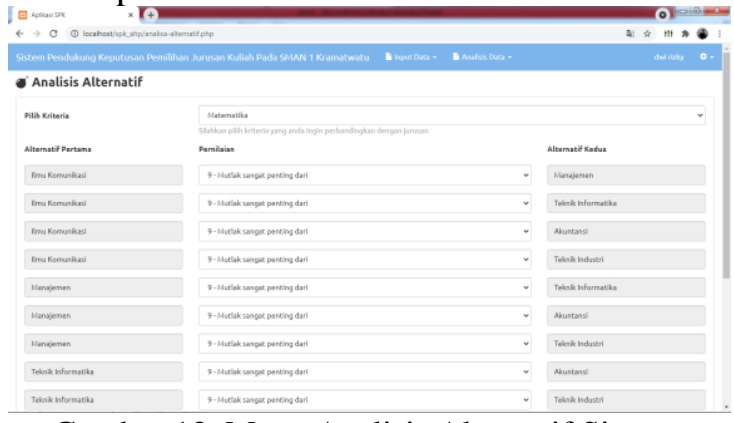

Gambar 13. Menu Analisis Alternatif Siswa

\section{J. Menu Perangkingan}

Halaman ini adalah menu perangkingan Siswa. Pada menu ini, Siswa dapat melihat perangkingan dari alternatif jurusan yang ada. Tampilan menu perangkingan dapat dilihat pada Gambar 14.

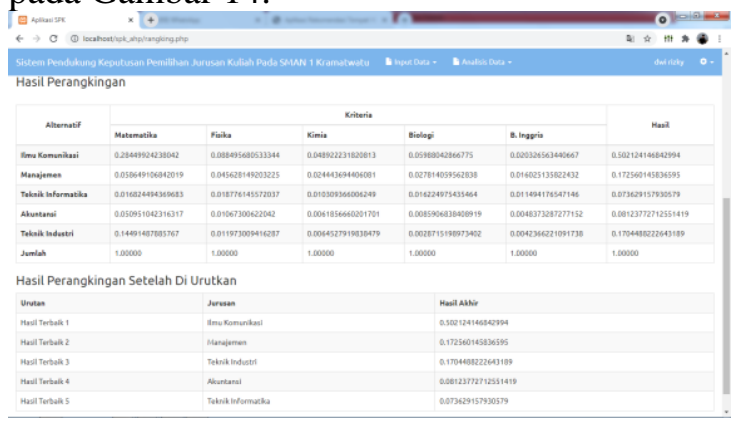

Gambar 14. Menu Perangkingan

\section{Kesimpulan}

Berdasarkan hasil dari analisis penelitian yang telah dilakukan,dapat diambil kesimpulan sebagai berikut:

A. Dengan dibuatnya aplikasi sistem pendukung keputusan pemilihan jurusan kuliah ini dapat membantu siswa dalam mendapatkan rekomendasi jurusan yang ingin diambil ketika melanjutkan pendidikan ke perguruan tinggi.

B. Dengan dibuatnya aplikasi sistem pendukung keputusan pemilihan jurusan kuliah ini dapat membantu pekerjaan guru BK untuk membimbing siswa yang ingin berkonsultasi tentang jurusan kuliah.

\section{Daftar Pustaka}

[1] N. Aeni Hidayah and E. Fetrina, "RANCANG BANGUN SISTEM PENDUKUNG KEPUTUSAN KENAIKAN JABATAN PEGAWAI DENGAN METODE PROFILE MATCHING (Studi Kasus: Kementerian 
Agama Kantor Wilayah DKI Jakarta)," Stud. Inform. J. Sist. Inf., vol. 10, no. 2, pp. 127-134, 2017.

[2] M. I. S, Mesran, D. Siregar, and Suginam, "Rancangan Pendukung Keputusan Pemilihan Televisi Berlangganan Menerapkan Metode Analytical Hierarchy Process(Ahp)," Media Inform. Budidarma, vol. 1, no. 2, pp. 42-48, 2017.

[3] $R$. Setyowati, $W$. Prabowo, and M. Yusuf, "Pengambilan Keputusan Menentukan Jurusan Kuliah Ditinjau Dari Student Self Efficacy Dan Persepsi Terhadap Harapan Orang Tua," J. Psikol. Pendidik. dan Konseling J. Kaji. Psikol. Pendidik. dan Bimbing. Konseling, vol. 5, no. 1, pp. 42-48, 2019, doi: 10.26858/jppk.v5i1.7460.

[4] M. Hanif, $R$. Hariyanto, and $A$. $A$. Widodo, "Sistem Pendukung Keputusan
Untuk Membantu Calon Siswa Memilih SMA Negeri di Kota Pasuruan Menggunakan Metode AHP," J I M P - J. Inform. Merdeka Pasuruan, vol. 5, no. 1, pp. 21-26, 2020, doi: 10.37438/jimp.v5i1.245.

[5] K. Yuliana and A. Aini, "Sistem Pendukung Keputusan Pemilihan Sekolah Dasar Menggunakan Metode Analytic Hierarchy Process (AHP) Pada Gugus Sungai Jingah Kecamatan Banjarmasin Utara," Infokam, vol. 1, no. 1, pp. 205-220, 2018, [Online]. Available:.

[6] D. S. Utomo, "Sistem Penunjang Keputusan Untuk Membantu Calon Siswa-Siswi Memilih SMK Di Malang Berbasis Mobile," J-Intech, vol. 8, no. 01, pp. 7-11, 2020, doi: 10.32664/jintech.v8i01.464. 